\title{
Migration as an opportunity for reinvention: Alfred and Margaret Rich of Gundaroo
}

JAMES MCDONALD

Along with their neighbours in the fledgling Taralga, Gundaroo and Gungahlin communities in the years 1857 to 1893, Alfred Mainwaring Rich and Margaret Phillips made valuable contributions to local life. ${ }^{1}$ For many years, they ran private schools and, thereby, held a key role in these communities, being responsible for the development of their children. To all who knew this couple in their adopted country, they appeared to be quintessentially English in character and heritage. When Alfred died in 1893, he was honoured with an obituary, which specifically noted his connections to the English landed gentry:

News has been received of the death of Mr. Alfred Mainwaring Rich, who died at the residence of his son at Gunning. The above-named gentleman who was highly connected-being the brother of the late Major General Rich-was formerly a resident here for many years and was well known both here and at Gundaroo. ${ }^{2}$

But all was not what it seemed. Alfred Rich had used his migration as an opportunity to omit certain elements from his past and to reinvent himself. Australia offered free settlers the chance to build new lives. Some took it further and built new identities. This is certainly what Alfred did, but, as this paper suggests, he may have paid a price for self-deception.

\footnotetext{
1 According to Parish records, Alfred Rich was baptised 3 March 1823 at Shinfield, Berkshire. Margaret Phillips was born in 1840 at Leeds (see her enumeration in the 1841 and 1851 England censuses).

2 Queanbeyan Age, 24 June 1893, 2. Alfred was the youngest of four brothers. The others were: Reverend Edward John William Henry Rich (1815-1895); Major-General William Charles Rich of the North India British Army (1818-1903); and Thomas Lionel Rich, Curate of Cambourne (b. 1820). William Charles Rich is the majorgeneral mentioned in the obituary, although he was not yet deceased, as claimed.
} 


\section{A rich heritage concealed}

It may be true that Alfred Mainwaring Rich's father was indeed of minor gentry stock, but the Richs were viewed as usurpers in England. The family had Jewish origins and had won its wealth and titles during the dissolution of the monasteries. ${ }^{3}$ As such, they were viewed as 'Shylocks', whose ancestors had profited from simony. They were also resented for taking the side of Parliament in the English Civil War. ${ }^{4}$ In these respects, they were considered 'gentry' in title only. Making matters worse for Alfred was that his mother's side had Mughal Indian heritage, and there is even evidence pointing to African ancestry through a manumitted slave on the South Atlantic island of St Helena. Alfred's mother's complexion was so dark that her British citizenship had to be explained to the 1851 census officer. In subsequent censuses some of her cousins were even described as 'African coloured'. ${ }^{5}$ He may well have been the first person of African heritage to visit the Limestone Plains. It would be interesting to imagine what the conservative Gundaroo and Gungahlin communities would have thought if they had discovered that they had entrusted the care and tutelage of their children to a teacher of mixed heritage. ${ }^{6}$

Margaret Phillips also shielded a non-Anglo past. She, too, came from a Jewish family on her mother's side. ${ }^{7}$ Her paternal line was nouveau riche, as the Phillips family had recently prospered as merchants in Leeds and through their marriage into the very wealthy, and very Quaker, Nicholson family of Roundhay Park, Leeds. ${ }^{8}$ Although her family was welcomed as philanthropists, employing, as it did, many locals and Waterloo veterans on the redevelopment of the parklands, it was never really embraced as an equal by the established local gentry.

3 The Rich family were London mercers, prominent in the area of St Lawrence Jewry. Richard Rich (c. 14971567) successfully navigated his way through senior bureaucratic positions in the reigns of Henry VIII, Edward VI, Mary I and Elizabeth I. He benefited from the dissolution of the monasteries and was raised the first Baron of Leez. He was said to have perjured himself in the trial of Thomas Moore. He was criticised for regularly switching sides and was even voted in 2005 by a BBC panel of historians as the 'worst Briton of the 16th century'. But his Jewish heritage is not widely known and his precarious position, as such, goes a long way to helping understand his actions. It was not until the Cromwellian Republic that the Jews were welcomed back into England after the purge and expulsion of 1290. See Simon Schama, A History of Britain (New York: Hyperion, 2000), 196-97; Robert Winder, Bloody Foreigners: The Story of Immigration to Britain (London: Little, Brown, 2004), 49-51.

4 Prominent Parliamentarians from the Rich family in the Civil War period were Robert Rich (second Earl of Warwick) and Henry Rich (first Earl of Holland). Alfred Rich was also descended from other pre-eminent Roundhead families, including John Hampden, Robert Pye (junior), the St Johns and Apsleys.

5 For example, Anne Brooke in the 1901 England census.

6 Prejudices on the basis of race, religion and culture were severe among the settler community in Ginninderra and Gungahlin. For example, Thomas Gribble senior told Samuel Shumack a story about his own family's views, when he heard that his son (Thomas Gribble junior) had married an Irish girl, even though she was from a Protestant planter family. He said that when his wife heard the news she broke down and cried, 'Oh Lord, what have we done that our son should disgrace his family and marry an Irish savage’. See Samuel Shumack, An Autobiography, or, Tales and Legends of Canberra Pioneers, ed. J. E. and Samuel Shumack (Canberra: Australian National University Press, 1967), 79-80.

7 Family members had been told that Margaret Phillips was Jewish. At present, no documentary proof has been found; however, recent DNA tests of the matrilineal line have corroborated the family story of Jewish descent.

8 Margeret's uncle, William Nicholson Phillips (post Nicholson), inherited the $£ 60,000$ Roundhay Park estate of his Quaker uncle, William Nicholson senior. See Neville Hurworth, 'The Life and Family of Thomas Nicholson of Roundhay Park', Oak Leaves (Oakwood and District Historical Society), part 1 (Spring 2001): 1-8. 


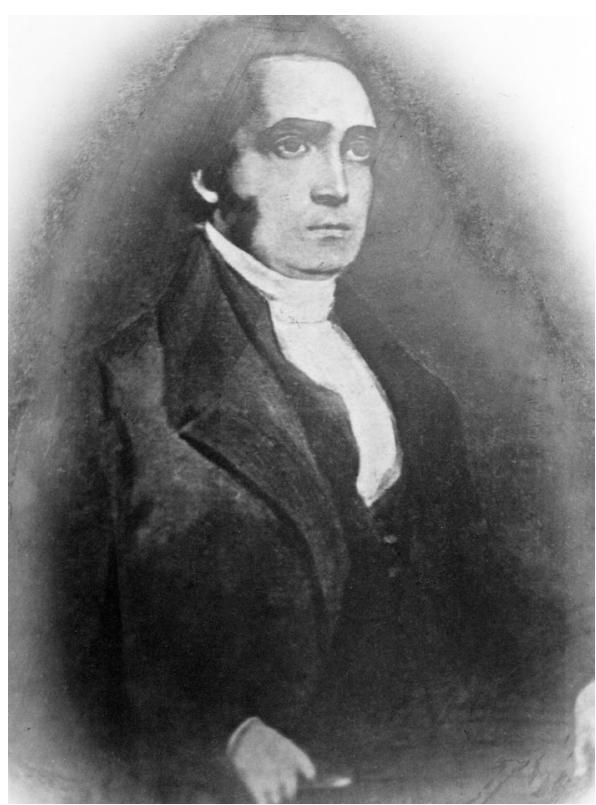

Figure 1: James Phillips, c. 1860.

Source: Author's collection.

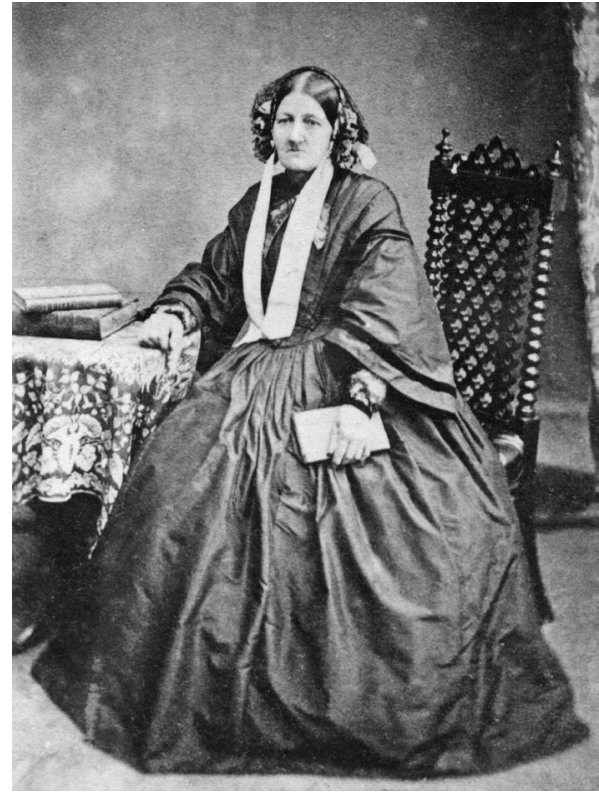

Figure 2: Margaret Rich (née Phillips), c. 1870 , Sydney.

Source: Author's collection.

Margaret's father, James Phillips, was widowed around 1840 and was busy establishing business interests across the world in concert with a few of his brothers. They traded cloth and other goods and even travelled to Australia, where they carved out the rural property 'Kareen', near Scone.' The family found places for Margaret and her cousins in a school for clergymen's children, similar to that attended by the Bronte sisters. ${ }^{10}$ This arrangement lasted until they could be brought out to New South Wales (NSW). ${ }^{11}$ Two of them, Margaret and her cousin Sarah, were educated as school tutors. When they arrived in the colony in 1859, the Phillips girls were presented as models of English gentlewomen and were both quickly married off to promising young school principals. ${ }^{12}$ The marriages may even have

9 'Kareen' was a 100-acre dairy farm near Scone, where James Phillips built a three-bedroom stone house. By the time his brother, Thomas, joined him, it was also renowned as a horse stud. See, for example, its description in the Scone Advocate, 29 December 1893, 3.

10 The Brontes's school, of course, was Cowan Bridge. The school attended by the Phillips girls was established in 1833 at Casterton, Cumbria. It is not known how the Phillips families managed to secure enrolment in what was primarily a charitable institution for the daughters of poor clergymen, but they might have been among a small number of 'paying customers' whose fees subsidised its operation for the broader enrolment. The Quaker network of the Nicholsons may also have been a factor in securing their candidature.

11 According to the passenger records for the Parsee, the girls migrated on assisted passage, which is remarkable, given the good financial position of the family. The family may have overstretched finances with the new venture in Australia, or perhaps they were simply taking advantage of the scheme to obtain a cheap fare.

12 Sarah's husband was John Beresford Boate (1824-1901), with whom she first settled at the Collector, Gundaroo and Sutton schools. See the NSW Teachers Rolls; Errol Lea-Scarlett, Gundaroo (Canberra: Roebuck Society, 1972), 39, 46, 76; Lyall L. Gillespie, Early Education and Schools in the Canberra Region (Campbell, ACT: L. Gillespie, 1999), 65-66, 85, 133, 141-42, 165. 
been prearranged. Margaret's uncle, Stephen Phillips, was himself a schoolmaster and probably acted as a remote matchmaker. It seems more than coincidence that both Phillips women quickly wed local teachers. Once the marriages were complete, the extended Phillips family had five teachers working in three schools across the Goulburn district.

James Phillips seems to have been a driven man, who had a clear plan for his children. Margaret was virtually an orphan. Her mother died when she was an infant and she would have barely known her father, who had placed her into boarding school at an early age before leaving the country to pursue his business interests. He only sent for her when a placement and possible marriage was arranged at the other end of the world. Remarkably, Margaret complied with his distant plans.

It was clear that both Alfred's and Margaret's families had long since converted to Christianity. But, while Alfred did his best to conceal knowledge of his heritage, the memory of Margaret's Jewish ancestry and her sense of difference was retained and passed down, albeit privately, within the family. Publicly, however, it was a very different matter.

Alfred's father was Charles Lewis Henry Pye Rich (1784-1840), who dissolved his family holdings in Berkshire to resettle in Somerset. He was half-French and had been born and raised in Amsterdam where his father was a banker and the Crown's part-time ambassador in the Netherlands. ${ }^{13}$ Alfred's mother, Maria Tippet (1798-1886), was related to Chovvakkaran Moosa (1745-1807), a Mughal pepper merchant of Thalaserry, who was so wealthy that he had lent money to the British East India Company. ${ }^{14}$ His mother also seems to have had African heritage through the Masons, who were planters on St Helena. Despite the considerable wealth of these families, it must have been hard for the mixed-race Tippets and Masons to find genuine acceptance in nineteenth-century England. ${ }^{15}$

13 Certificate from the register of the English Episcopal Church in Amsterdam.

14 For Moosa, see A. P. Ummer Kutty, Keyi Charitram (Thalaserry, 1916), 185-208; M. P. Mujeebu Rehman, 'Merchants, Colonialism and Indigenous Capital: Chovvakkaran Moosa and the English East India Company', Advances in Arts \& Ideas 3 (2007): 129-39. The connection to Moosa is confirmed in the will of William Henry Tippet, Magistrate of Patna (proved 1834), who married his daughter, Mussooruat Sauer Nhaunus.

15 Although it is not certain, it seems likely that the family's African heritage was first derived from Thomas Mason, who appears to have been a slave who won his freedom on St Helena by helping the reconstruction effort on the island after the brief Dutch annexation of 1673. He was probably freed around 1680. If the local minister and the St Helena Council could vouch for their good character, and if they had become Christians, slaves could be freed within seven years and were allowed to take up small landholdings and cattle allotments on the island, like any new planters. For Governor Field's manumission measure, see the extract from a letter to the St Helena Council from the Directors of the East India Company (dated 19 December 1673); cf. Thomas H. Brooke, History of the Island of St Helena: From Its Discovery By the Portuguese To the Year 1823, (London: Kingsbury, Parbury, and Allen, 1824), 101, and Hudson Ralph Janisch, Extracts From the St. Helena Records, (London: B. Grant, 1885), 2-3. It is ironic that when Captain James Cook visited St Helena in 1775 he was entertained by James Tippet and his fatherin-law's mixed-race family. Benjamin Mason's plantation was selected by the islanders as a 'model', showing Cook how the slaves on their plantations were well treated, as they had been harshly criticised by his colleague Joseph Banks four years before in 1771 . 
Army records show that Alfred enlisted on 12 August 1845 (aged 22) in LieutenantColonel H. K. Bloomfield's 1/11th North Devonshires, which served in Australia from 1845 to 1857 . Although the 1841 England census shows that Alfred had been apprenticed to a medical practitioner, his employer died and he did not complete his training. In his enlistment papers, Alfred's designation was 'labourer', which suggests that he had fallen upon hard times and may have been estranged from his wealthy family. ${ }^{16}$ There appears to have been a fundamental flaw in Alfred's character, but while he was living within the structure of his regiment or within the structure of his marriage, he seems to have been able to conceal it.

Upon arrival his regiment was posted to Hobart, but due to internal discipline problems with the existing troops in Sydney, the North Devonshires were redirected to help restore order in the city. The incumbents had become unpopular in Sydney for their rough treatment of civilians and convicts alike. In contrast, the North Devonshires proved to be a popular regiment, returning to garrison Sydney in response to a public petition in 1848. Thereafter the regiment occupied Victoria Barracks until it returned to England in 1857. At this time about 100 men purchased their discharge in order to remain in Sydney. According to the last NSW pay sheet of the regiment, Alfred was discharged at Sydney on 11 October 1857 with six months pay. He settled at Macarthur's property, Richlands, near Taralga, where he found employment as a schoolteacher. ${ }^{17}$ Margaret was also soon teaching at Richlands and they were married in the house of her uncle, Stephen Phillips, principal of the school. ${ }^{18}$

In Australia, Alfred had already begun sowing the rumour that his family had a castle and manorial holdings in England, and that he had only joined the army and left his native country in despair, having been blamed for a riding accident that took the life of his sister. ${ }^{19}$ These stories were inventions, but they were willingly consumed by his colonial friends and, ultimately, by his own children. Only after the investigations of his descendants, which began in the 1960s, was it discovered that there was no castle, no sister and no reluctant émigré. ${ }^{20}$ Even the profession that he claimed and, on occasion, practised (surgery) was an exaggeration. More recently,

16 Regimental records relating to Private Alfred Rich (number 2,451).

17 Lyall L. Gillespie, Ginninderra, Forerunner to Canberra: A History of the Ginninderra District (Campbell, ACT:

L. L. Gillespie, 1992), 238.

18 But note that the marriage certificate says they were wed in the house of $\mathrm{Mr}$ W. Phillips, which seems to be an error. Also note that Stephen Phillips established the first school at Taralga, which suggests that there was a preexisting realtionship with Alfred.

19 Family stories reported by his daughter, Sarah Reid (née Rich), and passed on to her grandchildren, Lyall Gillespie and Nell McDonald.

20 Alfred's grandson, Cecil Rich, travelled to England in the early 1960s to test the veracity of the family tradition and was the first to discover that there was little basis for many elements of the family tales. However, Cecil did unearth documentation that showed the Rich paternal line was part-French and, ultimately, of Jewish origin. 
his paternal Jewish heritage, his maternal Mughul roots and possible slave ancestry have also come to light, now that there is ready electronic access to records held in the India Office and the archives and parish registers of St Helena. ${ }^{21}$

In Alfred's defence, it must have been difficult for someone of mixed heritage to find acceptance in nineteenth-century English society. Perhaps Alfred saw the nonAnglo origin of his family as something best shed in the antipodes. In Gundaroo and Gungahlin, Alfred's dark complexion would not be scrutinised as it had been in conservative and more homogenous Somerset. People in the colony were perhaps thirstier for the more gentile elements of life from the old country, and this is what their gentrified schoolteachers, Alfred and Margaret, offered them. Moreover, in late nineteenth-century NSW, Alfred and Margaret could hope to be judged on their merits, rather than on their racial backgrounds. It is also noteworthy that both Margaret and Alfred were the youngest children in their respective families. Both, therefore, had to struggle a little harder to achieve success. In Australia there were more opportunities for those with the ability and energy to seize them.

\section{The Gundaroo and Gungahlin years}

Around 1867 Alfred and Margaret moved to Nelanglo (now Bellmount Forest), near Gundaroo. Here they combined farming with the provision of teaching services. In the 1840s, the prime riverfront acreage at Gundaroo had been secured in large parcels by a small number of established families, including the McLeods at Barnsdale, the Dyces at Tillygrieg, the Packers at Esther Mead, and the Guises (ex-squatters) at Jerrabiggery. ${ }^{22}$ The bulk of the Gundaroo workforce consisted first of convicts, then, after transportation ceased in 1840, there came a flow of 'bounty migrants'. In the 1841 NSW population census the place was listed as having 388 inhabitants. Convict representation had dropped significantly with only 90 remaining. By the time the Richs arrived in the mid-1860s, the population was mainly composed of tenant farmers or small landholders. In the 1850s a number of the larger properties had been broken up for tenant farmers and a new influx of smaller free selectors, who had humbler origins but enough capital and motivation to take advantage of the opportunity to buy good land. ${ }^{23}$

It was into this maturing community that Alfred and Margaret arrived to set up school to the north of Gundaroo. Just 18 months later, Margaret's sister Sarah and her schoolmaster husband, John Beresford Boate, ran schools at Gundaroo and

\footnotetext{
21 Note that the early St Helena records can now be accessed through the British Library's 'Endangered Archives Project' (eap.bl.uk/database/results.a4d?projID=EAP524) and the University of the Witwatersrand (www.historical papers.wits.ac.za/?inventory/U/collections\&c=AB2073/R/).

22 Lea-Scarlett, Gundaroo, 1-18.

23 An example would be the Read/Reid families from Tintinhull in Somerset, who are still in the district to this day. See Lyall L. Gillespie, A Pictorial History of the Read/Reid Family in Australia, 1849-1879 (Campbell, ACT: L. L. Gillespie, 1979), 3-8.
} 
neighbouring Sutton from July 1868 until May 1873. Although the two families were not financially influential within the Gundaroo community, they wielded significant influence in the area and enjoyed a privileged position in its civic life. As 'local gentry', who were also responsible for the education of the district's children, they would have been viewed as cultural exemplars and intellectual leaders. Alfred was actively interested in literature and dabbled in comic verse that he occasionally submitted to the Goulburn Penny Post under the nom de plume 'Jeremiah'. ${ }^{24} \mathrm{He}$ even provided valuable ad hoc medical assistance and is recorded as having been friendly with the local medical practitioner, Dr Hidler. ${ }^{25}$ Alfred himself was called upon, on occasion, to provide emergency medical assistance. For example, in 1879 Curtis Dyce, a workman on the Gundaroo bridge, slipped and badly broke his leg. Alfred successfully set the fractured limb. ${ }^{26}$

But Gundaroo in the 1860 s was a relatively polarised community. It could be argued that the Richs and Boates would not have related closely to the local Irish, many of them Catholic, Gaelic-speaking emancipists or bounty migrants, who tended to congregate in clusters of smaller holdings at Mugwell, Back Creek and towards Tallagandra. ${ }^{27}$ Conversely it could also be argued that many Irish would not have wanted Alfred and Margaret to be their social mentors. Common ground for the Richs and Boates would have been found with the Protestant landowners and their families located along the river frontages and in the new township itself. In this context, Alfred and Margaret would have presented themselves as orthodox Anglicans. The Catholics, on the other hand, had no church of their own; worshipping instead at makeshift altars set up by Michael Brennan, the resident priest at Yass, or itinerant clergy visiting from St Mary's in Sydney. ${ }^{28}$ The first Catholic church at Gundaroo, St Josephs, was not built until $1881 .^{29}$ Thankfully the intermingling of cultures and perspectives in the new country would eventually dilute these prejudices. For example, the Presbyterian Gundaroo squire Donald McLeod junior donated some his family's land to be used as a non-denominational cemetery (primarily by local Catholic families), when Rev. Galliard Smith refused to bury non-Anglicans in the general cemetery. ${ }^{30}$

\footnotetext{
24 Republished in Lyall L. Gillespie, Early Verse of the Canberra Region: A Collection of Poetry, Verse and Doggerel from Newspapers, Other Publications and Private Sources (Campbell, ACT: L. L. Gillespie, 1994), 29.

25 Shumack, An Autobiography, 105. It is interesting that Dr Hidler is described by Shumack as a reformed alcoholic. Alfred also appears to have been 'on the wagon' while Margaret was alive, and the two men may have found support in each other's experiences battling alcohol dependency.

26 Lea-Scarlett, Gundaroo, 96.

27 Speaking Irish by convicts in Australia invoked a penalty of 15 lashes, yet it was still the common language of Irish immigrants in the 1820s. See C. Fritz, 'Language, Change and Identity: The Irish in Nineteenth-century Australia', in Irish-Australian Studies: Papers Delivered at the Ninth Irish-Australian Conference, Galway, April 1997, ed. Tadhg Foley and Fiona Bateman (Sydney: Crossing Press, 2000), 57-66.

28 For a summary of Fr Brennan's career, see Nepean Times, 4 August 1914, 8; Brian Maher, Planting the Celtic Cross: Foundations of the Catholic Archdiocese of Canberra and Goulburn (Canberra: B. Maher, 1997), 93, 98, 101-4, 109, 115-16, 119, 294; Brian Maher, ed., Sesquicentenary 1862-2012: Diocese of Goulburn, 1862-1948; Archdiocese of Canberra and Goulburn, 1948-2012 (Canberra: Rev. Brian Maher, 2012), 58.

29 Lea-Scarlett, Gundaroo, 39.

30 Lea-Scarlett, Gundaroo, 52-53, 101, 146; McLeod's generosity is recognised at the cemetery in a plaque.
} 
But just as the couple had created new lives for themselves at the centre of their adopted community, tragedy descended. Margaret died unexpectedly in May 1880 at her residence in Nelanglo. The cause of death was 'internal abscess', for which she received treatment over a six-day period. She was buried in Gundaroo general cemetery in an unmarked grave. ${ }^{31}$ Alfred struggled to cope after his wife's death. As suggested above, it seems that he had an unstable temperament, unsuited to grief. Matters may not have been helped by the fact that he was living a life of halftruths. His financial position was poor and he proved unable to provide for his five surviving children, who ranged in age from 13 years to a few months. Alfred junior, the eldest, sought farm work at Gunning. The directories and other records show that, eventually, he became a labourer at Goulburn. Sarah (aged 10) remained with her father for a few years before taking up a domestic position with the Collett family at Queanbeyan. She later married Richard Reid, an emerging grazier at Spring Flat, Tallagandra. The youngest children were fostered out. Honorah Cartwright (née Reid) of Tallagandra took in Frances (aged six). Florence went to live with the Jones family at Gundaroo and later married their son. Lionel, a baby of just five months, was fostered by the Elliotts in Sydney. ${ }^{32}$

In August 1881 Alfred moved to Gungahlin, where he established a small private school located on premises adjacent to the Anglican stalwarts, the Gribbles. ${ }^{33} \mathrm{He}$ ran the school for several years, servicing Gungahlin, Ginninderra, Mulligans Flat and Tea Gardens, but closed it, in March 1892, when enrolments waned and his health started to fail. He took the opportunity to retire to Gunning, where he lived with his son. ${ }^{34}$ After Margaret's death he turned to alcohol. As we have seen, the children had already been 'farmed out'. Some financial respite came when his mother died in 1886 , and he seems to have been in receipt of a stipend from her estate thereafter. ${ }^{35}$ But at some time before he died, the payments he was receiving from England also ceased. It is said that Rev. Galliard Smith, through whom the payments were administered, had reported his heavy drinking bouts to the trustees of the estate. ${ }^{36}$ Temperance, it seems, must have been a condition upon which the payments were predicated. Despite Alfred's shortcomings, it seems clear that he was a well-educated and talented man, able to turn his hand to soldiery, teaching, farming and medicine. He appeared to be the sort of 'refined English gentleman' who people admired and whose flaws (such as his drinking) were readily overlooked. He died in June 1893 at Gunning, aged 70, and, like his wife, was also interred in an unmarked grave. ${ }^{37}$

\footnotetext{
31 NSW death certificate.

32 Gillespie, A Pictorial History of the Read/Reid Family, 12.

33 Goulburn Evening Penny Post, 23 August 1881, 4. Cf. Gillespie, Early Education and Schools, 36-37, 139.

34 See Lyall L. Gillespie, 'Ginninderra: A Centre of Early Education', Canberra Historical Journal, n.s. 12, (September 1983): 27-33; Lyall Gillespie, Canberra: 1820-1913 (Canberra: AGPS Press, 1991), 92; Gillespie, Ginninderra, 61, 204, 238; Gillespie, Early Education and Schools, 36-37.

35 He also may have acted as an agent in Australia of his brother, Thomas Rich, who had investments in the newly founded Bank of Australasia (the investment is noted in the 1861 England census).

36 Lyall Gillespie reported to me in 2004 that his father, William Gillespie, contacted Rev. Smith's daughter, who confirmed the stories, but was unable to secure copies of the relevant correspondence.

37 Recently descendants have made arrangements for plaques to be positioned at both graves.
} 


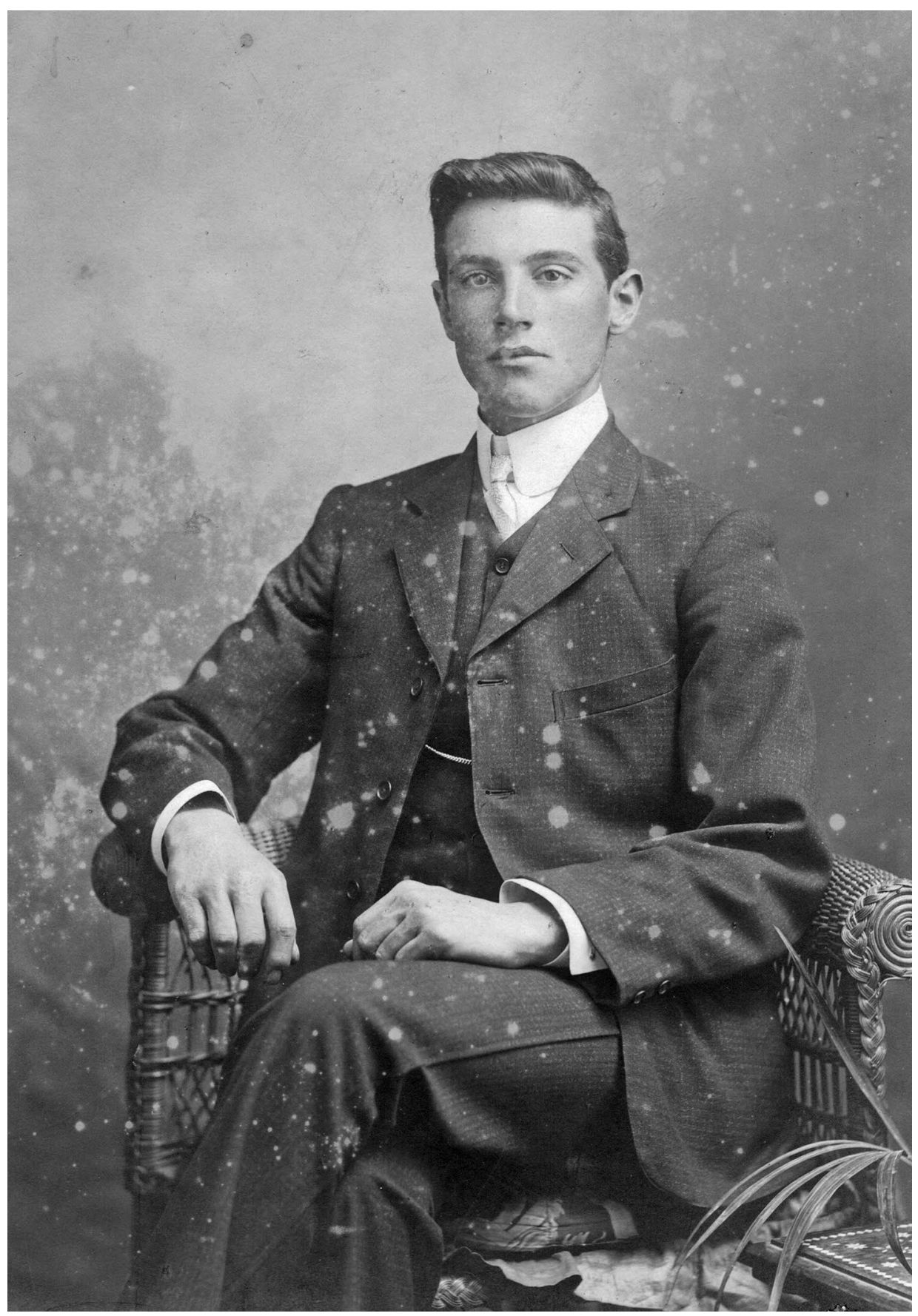

Figure 3: Alfred Mainwaring Rich junior, c. 1890, Goulburn.

Source: Author's collection. 


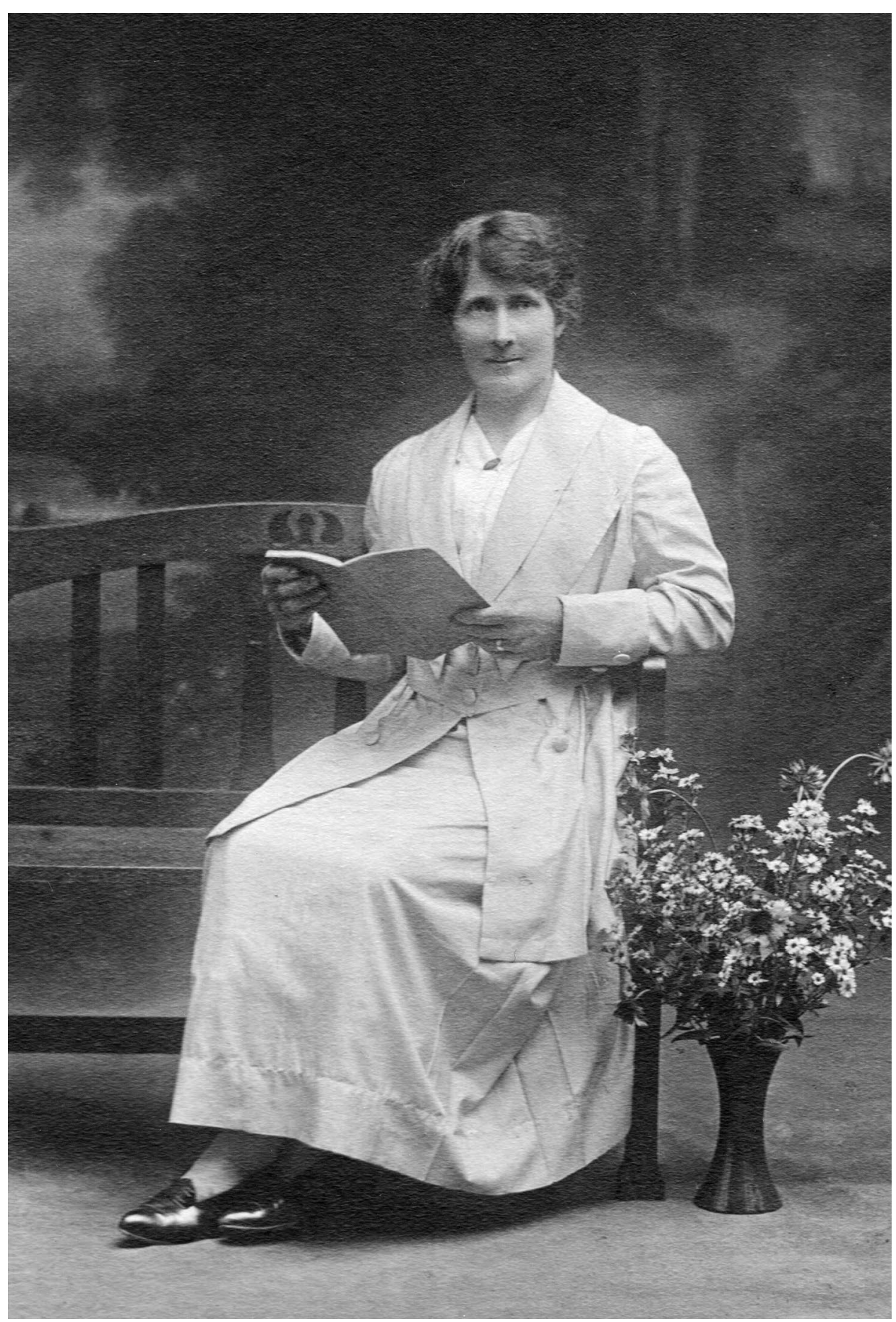

Figure 4: Sarah Reid (née Rich), c. 1910, Sydney.

Source: Author's collection. 
Although relatively little is known about them, there is enough information to support the gist of the story that Alfred Rich left England deliberately to seek out a new and obscure life for himself, even if the detail of the circumstances was invented. We can never know what his reasons were, but it seems likely that it was a deliberate process of reinvention. What is certain is that he and Margaret were happy together and raised a fine family. But what is also apparent is that, after Margaret died, Alfred did not cope on his own. The people of Gundaroo and Gungahlin probably had no idea that African, Indian and Jewish blood ran through Alfred and Margaret's collective veins. Their neighbours in England would have known, or suspected, and probably not have embraced them in the way that the Australian communities did. Overall, it must be said, therefore, that their reinvention in Australia was a success. Most colonials wanted to believe that, in their midst, grew scions of English gentry grafted onto rough Australian bush-stock. It may have made them feel less distant from the memory of their own British homes. 
This text is taken from Australian Journal of Biography and History: No. 2, 2019, published 2019 by ANU Press, The Australian National University, Canberra, Australia.

doi.org/10.22459/AJBH.2019.04 